\title{
Implementation of Business Policy to Increase Income for Family Welfare (IIFW) to Support Population Program in Indonesia
}

\author{
Heru Irianto $^{1}$, Haryono ${ }^{1}$, J. Andy Hartanto ${ }^{2} \&$ Rr Herini Siti Aisyah ${ }^{3}$ \\ ${ }^{1}$ Universitas Bhayangkara Surabaya, Indonesia \\ ${ }^{2}$ Universitas Narotama Surabaya, Indonesia \\ ${ }^{3}$ Universitas Airlangga Surabaya, Indonesia \\ Correspondence: Heru Irianto, Universitas Bhayangkara Surabaya, Indonesia. E-mail: heru@ubhara.ac.id
}

Received: August 12, 2016 Accepted: September 26, 2016 Online Published: April 25, 2018

doi:10.5539/par.v7n1p51 URL: http://dx.doi.org/10.5539/par.v7n1p51

\begin{abstract}
Population problems are closely related to the economic and social conditions of the people due to the lower level of education and economy so that the awareness to follow the family planning program is low and lacks access to the available facilities and information. The independence of the family's economic is very important, considering that poverty not only affects the economic problems but also impacts on other issues such as life attitudes, family education, health and others which greatly influence the improvement of the quality of the human resources in Indonesia. In implementing the policy, synergicity of various elements of government institutions, communities, business institutions, such as working training centers, financial institutions, business and educational institutions and non-governmental organizations (NGOs), as well as mass media is strongly needed. With the paradigm of mutualistic symbiosis, the business continuity will be more secure and be able to support and promote each other for the same sake of developing and improving the condition through IIFW. In the era of regional autonomy in Indonesia, all existing local potential can be explored thoroughly to establish the synergicity so that the improvement of the economy in the region, especially, in the areas of the poor can be reached.
\end{abstract}

Keywords: family, entrepreneurship, population, poverty

\section{Introduction}

The business Policy to Increase Income for Family Welfare (IIFW) has started since the new order government. Its development, however, has been ups and downs in tune with the political situation in Indonesia. The emergence of various regulatory reforms have been issued as the government policy to support the success of the program such as Act no. 10 of 1992, Inpres No. 3 of 1996, Presidential Regulation no. 7 of 2005, and Global Commitment on MDGs (Mellinium Develoment Gold). IIFW is a comprehensive and holistic policy to overcome the problems of population and economy although its implementation is still sectoral. That is why a synergicity is necessary to make the existence effective and efficient (Lismomon Nata, http://sumbar.bkkbn.go.id)

Improving the economic capacity of the family in entrepreneurship through IIFW is important because the population problems are experienced by the poor. The goals of IIFW program can be sucessfully applied by way of monitoring and re-fostering to each village or by providing capital loans, training, marketing the business products and developing the business. (Susanti: 2013)

The poor communities have some difficulties in accessing family planning facilities and services due to some various economic limitations. Some necessary interferences in entrepreneurship from various parties who care about the problems of poverty or population or marginal groups are highly expected so that the program can be a Model in improving the family economy of the welfare of the family planning acceptors. It is seen as an important and strategic way in addressing various problems of poverty, health, human resources, and so forth. In accordance with the local conditions and authorities, it is hoped that the local wisdoms are able to provide more spaces for cross-sectoral synergy and participation of all stakeholders in improving the family economy of the family planning of acceptors.

The study aims to examine the implementation of IIFW policy whether it is effective to overcome the poverty 
and demographic problems in the region and to solve other problems such as unemployment, health, quality of human resources and others. The synergy of both legislative and executive parties is seriously needed to empower the families and to build a network of cooperation of all parties, including the private parties, and the importance of family-based economic empowerment based on the local culture. (Sarwirini, 2011: 52)

\section{Review}

The economic crisis in Indonesia had an impact on the economic pressures on the people, especially, the lower classes. It reduced their ability to access or to use contraceptives while the family planning officers were no longer supported by the government so that programs became stuck and even declined. (Nunung Nurwati, 2006). The purpose of IIFW itself is to increase the family income, to solve the economic problems of the family planning participants.

IIFW policy is a strategic effort to improve the quality of human resources (HR) in the future, and to accelerate the efforts of poverty alleviation of the participants of family planning program. It is an absolute priority of IIFW policy. (http://kaltim.bkkbn.go.id/Lists/Artikel).

Families with the resilience or toughness will be able to overcome their problems so that their prosperity can be achieved. Therefore, some efforts should be made to enable the family to develop a system of trusts and responsibilities (Sudarsono, 2009). Implementation of family planning will be effective if there is an improvement of economic access and the importance of local, national and even international partnership because population problems cannot be overcome without actively involving all parties. (Dewi Amartani, 2014)

The family economy can be improved through IIFW program and is expected to increase the number of family planning participants (Yulaecha Padma, http://bkbpppa.tanahbumbukab) While the forms of activities in IIFW are (http: //kebumen.ipkbjateng): Utilizing the resources in conducting productive economy activities; Increasing the capacity of entrepreneurship of members; Building the partnership with the various supporting elements from various circles, especially, in the effort of coaching, training, and mentoring.

The state policy related to the family economic improvement efforts of the family planning participants, IIFW, has been done since the New Order era. Now it still runs but is not effective; There are several causes and they are as follows: (1). Low commitment of local governments. (2). Reduced number of program managers in districts / municipalities, sub-districts and villages/countries who can do coaching. (3). Lack of Information and Education Communication (IEC) on the benefits of family planning programs for IIFW group members to join family planning. (4). Minimal socialization about IIFW program in the grassroots. (5). Frequent occurrence of misuse of IIFW program. (6). Lack of accessibility in obtaining information about IIFW program. (7). Target fulfillment is a measure of the success of a program, while in the field there are still many IIFW groups need to be fostered, and the existing human resources are limited. (Anoname, 2011: 1).

The other things that hamper IIFW progress are the traditional management and lack of access so that when experiencing difficulties in capital or partners to develop their business they cannot make any improvement (https://visitkalibawang.wordpress.com).

CSR Fund is a potential fund to empower the local communities by developing the entrepreneurship. It can be used as an alternative model suitable to establish the partnerships between companies and communities around. The key is the synergy of all stakeholders to play an active role to optimize the implementation of CSR for the prevention of unemployment. (Heru Irianto (204)

In some cases, there are some groups that have developed but without any innovation in their products so that they cannot compete in the market. Beside that there are also some with no fixed markets so the production process does not run smoothly, not to mention the problem of the organizational and financial management, Administration and others that make the progress of the IIFW groups run slowly (Bernas Jogja, Monday: 2013,)

One of the strategies in public policy implementation is Partnership approach. It is the partnership between the government and the people, especially, those who have commitment to share concern and problems. The goal is to increase efficiency on the government side as well as sharpen the vision of service to the community.

\section{Method}

The study is related to the implementation of IIFW as a driver of the entrepreneurial growth for the poor families. A qualitative approach with a multidisciplinary background of the Study Programs in Social and Political Sciences, Economics, and Business and Law was applied. It was done in a district of the local government of Ngawai in East Java. It was chosen because Ngawi is located in the western part of East Java and it is as the border area which is usually marginalized since the poor people get less attention from the government. 
The objective of the research is to improve the effectiveness of IIFW implementation as a strategic policy to empower the poor people and their successes are expected to give a positive impact on various sides of the community life that ends to prosper the family and improve the quality of the human resources.

The main sources of this research are the local government, and the community leaders. The sources of information are determined by Snow Bolling with entry point from IIFW, participatory observation and Focus Group Discussion (FGD) involving all stakeholders of local government, companies, community leaders, unemployed persons, non-governmental organizations and universities. Snow Bolling is applied to obtain some continuous and cumulative data from various sources involved in IIFW program, and then those data are extracted correctly, accurately, holistically and comprehensively.

Through this method, some input from various parties is expected and the results can be implemented optimally. In accordance with the use of qualitative approach in this study, the in-depth interview technique is used to obtain the data because this technique is very appropriate to obtain data related to the organizational activities, motivation, behavior and so on (Heru Irianto 2001) It is conducted with a view to get deep information and comprehensive data related to the factors of ineffective implementation of IIFW Policy and of positive sides to improve the effectiveness and efficiency in the implementation of family planning program. After that the results are discussed in the Focus Group Discussion technique to get much deeper information related to Problem Solving

\section{Results and Discussion}

\subsection{Establishment Process of IIFW}

The establishment of IIFW can be done through the following process: (1) Identification of environmental and group potency. This activity is meant to recognize the business opportunities, and the capabilities of the human resources and group so that the possibility of success of the business can be clearly described. (2) Group forming. Developing IIFW into a dynamic group is always based on the principle of kinship which encourages the family members to join and continue to play an active role. (3) Establishing an egalitarian and open communication as well as deliberation among the members. (4) Conducting coaching and training directed to the routine guidance done by the board or the government agencies, private organizations or NGOs.

After forming the group, the next steps to take are the consideration and determination of the type of business to be developed. Some imporatant things must be highly considered in setting the right type of business to grow. The interest of the group members to the chosen business becomes the key to success beside some previous trainings to improve the skills.

Business will be able to grow faster if the members have the skills and interests. Sometimes, in this case, no training is required. The type of business to be chosen should also consider the availability of raw materials; It would be better to utilize local, easy, and inexpensive raw materials available in the local area so that it can significantly reduce the costs.

It is also expected to involve many people in an economic activity. The most important consideration is whether there is a local raw material that is easy to obtain with a cheap price so that the cost of production is relatively low resulting in the competitive price of selling the product. If in the business required an equipment, then cultivated pelaralatan simple, cheap funds easy to operate and maintenance does not require a high cost.

Another thing to consider is that the products are needed by many people or in accordance with the market demand. It means that the type of business is tailored to the needs and capabilities of people and the product price can compete with other products. Then the production process is not too long and difficult so that the capital turnover is also fast.

\subsection{Factors Inhibiting the Development of IIFW}

Implementing government policy on IIFW is not an easy thing to do since there are many complex problems. A strong drive involving many participative and voluntary parties is definitely required to succeed it; Such activities which are continuously done also require a serious concern. It is not just a short-term program but a long-term one to complete for the gain of success.

The program will succeed if many parties, such as the government, the community leaders, women organizations, universities, private companies or caring and creative youth groups, are actively involed. There is a proverb saying that: "Maintaing the achievement is much more difficult than reaching it". It also applies to the establishment and development of IIFW. There are many facts in the field that some IIFW established cannot last longer since the establishment sometimes seem only to meet the targets of government programs and the 
sustainability is not considered to be the first important priority.

Hindering factors related to the development of IIFW include the following:

\subsubsection{Institutional}

Given the political changes in Indonesia, the support of the central government agencies to develop IIFW experienced some setbacks. In Ngawi regency the development of IIFW is the duty and responsibility of the Women and Family Planning Service. In the implementation there has been no synergicity among the existing agencies so that the Women and Family Planning Service seem to run on its own, even the other departments/services have their own entrepreneurship training groups and sometimes even in the same community groups. Therefore, it is necessary to have synergicity between the existing departments/ services so that the problems in the group Community can be solved together comprehensively and holisitically.

\subsubsection{Human Resources}

The limitations of Human Resources (HR) both in quantity and quality are not not only in the community (IIFW) but also in the government department/service. Some employees are seriously required to provide guidance for IIFW to solve the problems. The low quality of human resources in IIFW shows the inability of the IIFW groups to innovate or have creativity when facing some problems in running their business. The condition results in the stagnant growth of the business. They are unable to solve the problems due to the limited knowledge in developing the products in order to attract the market. Creative ideas are needed to develope IIFW so as to take some advantages of the hidden or unthinkable local potential and even the emergence can sometimes be unexpected. The more creative ideas arise, the more local potential is developed. It can lead to some opportunities to develop IIFW or to take any risks. At this point the quality of human resources becomes an important factor.

\subsubsection{Working Capital}

Of the existing IIFW in Ngawi regency, only about $30 \%$ which still manage to survive. They are still trying to grow in spite of the limited working capital. That is why they are less developed. The women and family planning service cannot provide capital work because of the new government policy. Therefore, it is necessary to access the financial institution that can provide the working capital loans for IIFW to grow. Although there are various government programs for MSME credit, but getting a working capital loan from a Bank is required some assistance.

\subsubsection{Limitations of Market Access.}

Market is the key to success in enterpreneurship. Although the production capability is high, if the products cannot be absorbed by the market, it will result in the death of business. The development of IIFW is constrained by the marketing of the products because it is is still difficult to access the remote areas there. Another obstacle is the limited production capacity to serve the surrounding community so that sales can not be increased. Considering those problems, the government has facilitated IIFW to participate in some exhibitions in certain events at the local, national and even international levels, but it is still considered insufficient to market the products. At last the media engagement is needed to promote IIFW products.

\subsection{Design of Business Development for Increasing Income of Welfare Family}

Developing IIFW as a program of the population service is a very strategic program to solve various demographic problems at once. The success of IIFW will be able to solve the problems of economy, population, health, Human Resources, as well as unemployment. Although the focus of IIFW is on the empowerment of the poor to be entrepreneurial, every activity is always associated with the population problems. Thus, the concept is like a proverb saying that: "Two islands are exceeded in once rowing." If IIFW is such a great succeed, the problem of poverty will be overcome since the opening of a business has a high multiplier effect.

It is necessary to have various principal thoughts and principles adhered and obyed in building a strong business group. The principles of the establishment and development of the productive economic groups of IIFW are as follows: (a) Forming a productive economic group can take some advantages of existing institutions in the village, such as religious, youth, local community, and neighboring groups or establising the new ones. (b) Group formation is based on the needs of group members in order to increase family income. (c) Avoiding to force forming any other groups. (d) Holding socio-economic activities and developing family planning independently.

The development process IIFW can be done as follows: 
(1) Identification of environmental and group potency. This activity is meant to recognize the business opportunities, and the capabilities of the human resources and group so that the possibility of success of the business can be clearly described. (2) Group forming. Developing IIFW into a dynamic group is always based on the principle of kinship which encourages the family members to join and continue to play an active role. (3) Establishing an egalitarian and open communication as well as deliberation among the members. (4) Conducting coaching and training directed to the routine guidance done by the board or the government agencies, private organizations or NGOs.

After forming the group, the next steps to take are the consideration and determination of the type of business to be developed. Some imporatant things must be highly considered in setting the right type of business to grow. The interest of the group members to the chosen business becomes the key to success beside some previous trainings to improve the skills.

Business will be able to grow faster if the members have the skills and interests. Sometimes, in this case, no training is required. The type of business to be chosen should also consider the availability of raw materials; It would be better to utilize local, easy, and inexpensive raw materials available in the local area so that it can significantly reduce the costs.

It is also expected that the business activity results in an economic chain involving more people. The availabilty of some local raw materials and the relatively low production costs will lead to the cheap price so that the selling value of products is competitive. If quipment is required in running the business, the cheap and simple one (easy to operate and lower in maintenance) will be the choice.

Another thing to consider is that the products are needed by many people or in accordance with the market demand. It means that the type of business is tailored to the needs and capabilities of people and the product price can compete with other products. Then the production process is not too long and difficult so that the capital turnover is also fast.

The main problem in the initial establishment of IIFW is classic - the availability of working capital. This is a major problem for poor families who do not have any access to the business capital for business. Associated with this problem, some ways are offered to obtain the working capital by: (1) Membership dues, by way of regular contributions of group members. (2) Assistance from the local government in accordance with the program of each sector based on the budget of the productive economic business. (3) Loans for working capital of state-owned enterprises. (4) Sponsorship Assistance, it is from a company that is interested in helping.. (5) Working capital may also be obtained from a bank loan with a lower interest usually provided by a designated government bank. It is specifically for Small and Micro Enterprises and under the recommendation of the local family planning board to obtain business capital assistance through the credit scheme.

The implementation of the government policy on IIFW is not an easy thing to do since there are many complex problems. A strong drive involving many participative and voluntary parties is definitely required to succeed it; Such activities which are continuously done also require a serious concern. It is not just a short-term program but a long-term one to complete for the gain of success. The program will succeed if many parties, such as the government, the community leaders, women organizations, universities, private companies or caring and creative youth groups, are actively involed.

In developing IIFW some creative ideas are needed so as to take some advantages of the hidden or unthinkable local potential and the emergence can sometimes be unpredictable. The more creative ideas can be the trigger of developing the more local potential and open more opportunities for IIFW to grow. The creative ideas, however, are sometimes not supported by the majority of te community groups as well as other institutions including the financial one so that they have to work on their own to realize their ideas to succeed the program and be followed by many people around.

Another obstacle is the problem related to the ability of IIFW to market their products and, in this case, the role of the local government is needed, especially, in the introduction of the products to a wider market. By the Government assistance, IIFW is supported to frequently attend some exhibitions in certain events at local, national and even international levelsIn addition to increasing the marketing turnover, the local government can make a policy for the people to buy and use IIFW products. It is very helpful to increase the sales s.

There is a proverb saying that:"Maintaing the achievement is much more difficult than reaching it". It also applies to the establishment and development of IIFW. There are many facts in the field that some IIFW established cannot last longer since the establishment sometimes seem only to meet the targets of government programs and the sustainability is not considered to be the first important priority. 
Another difficulty to develop IIFW is the culture of the people who are still less appreciative or interested in the product of the nation itself. Actually the quality of the product is not inferior to the ones from abroad although the price is much cheaper. To overcome the problem, it is necessary to have some promotions to the wider community and to make them prefer to use the local products.

The following is the Model Design of Business Development for Increasing Income of Welfare Family which is expected to be able to simplify the problem and to improve the development of IIWF. Various obstacles are seen in it. The synergicity of all stakeholders to participate optimally is required so that the priority of the program can be determined according to the local issues and potentials for IIWF to grow.

\section{SYNERGICITY MODEL DESIGN OF \\ IIWF POLICY IMPLEMENTATION}

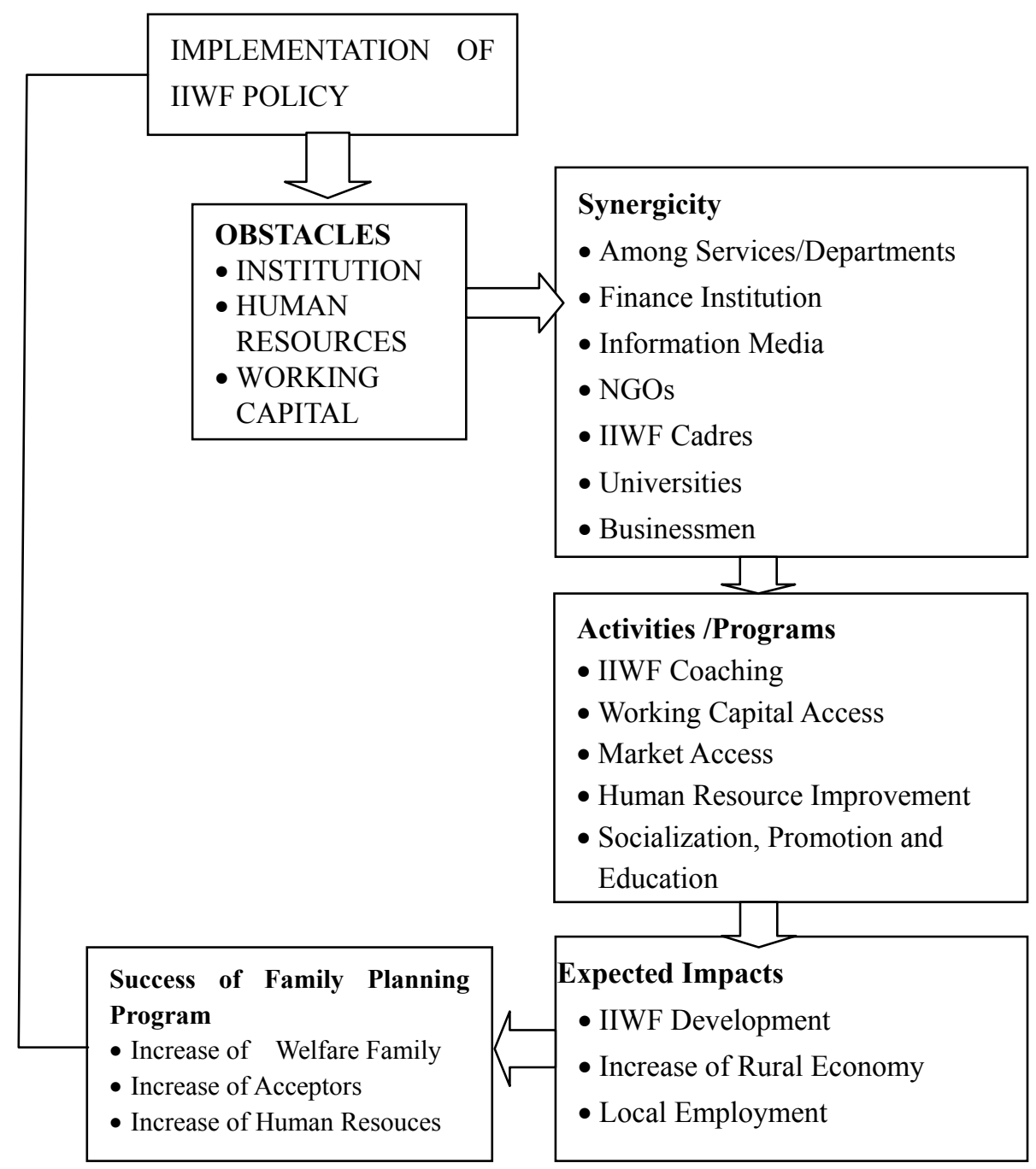

To overcome the obstacles in IIFW development, sinergicity involving the local government agencies, especially, the Female and Family Planning Services as the leading sector, Cooperation Service, Small and Medium Enterprises (MSMEs), Industry and Labor Service must be done. In the era of autonomy each region in Indonesia has the tasks and responsibilities to support the program for the advancement of the community.

The financial institutions, such as banks and cooperations, can provide some assistance in the form of working capital for IIFW to run and develop their business. In this case there is a mutualist symbiosis because the financial institutions also desperately need successful entrepreneurs as their clients while IIFW requires the working capital to support its business.

Mass media have an important role in the development of entrepreneurial. They educate the people how to promote the products produced by IIFW. In Ngawi Regency there are more than 25 communities of radio 
stations that are ready to cooperate with some various parties concerning about the development of IIFW. Some events have been appoved to schedule regularly on Radio during the year of 2017 and to continue encouraging the progress of IIFW in particular and entrepreneurship in general.

IIFW cadres as the spearhead in entrepreneurship development are volunteers who really care about the problems faced by IIFW. They should be encouraged to continue learning to solve the never ending problems of business so that some assistances in the field are required.

The role of universities in the implementation of IIFW is very important and strategic as well as very much in line with the provision of one of the university functions as an agent of change in development. They use the Community Development approach in implementing the IIFW programs because it can involve various stakeholders in the community so that all can participate to synergize in developing their respective potential optimally. They can give their contribution as the initiators, facilitators, motivators, coordinators, and counselors in synergizing all stakeholders who wish to participate in IIFW development. Even as a center of science they are able to be the locomotive for IIFW progress.

Business institutions can also take a role in developing IIFW. The advanced business actors can become the partners of IIFW who want to expand their business. In Ngawi regency partnership is very necessary for product marketing or a place to study or apprentice for people who will establish IIFW. Thus, there is a learning process for the people who want to run a business and market the products leading to mutualistic symbiosis. The sucessful MSMEs can also motivate and consult for IIFW development.

\section{Conclusion}

IIFW is one of the most strategic approaches to strengthen the rate of success of the population programs in Indonesia. It is a program for poor families to access the family planning program facilities so that they are motivated to participate in family planning programs. Self-reliance in managing these activities is the key to long-term success. Such economic activities can flourish and have an impact on increased income of IIFW group members; Thus in the long run IIWF program will improve the quality of human resources. The success will be able to solve the problems of economy, population, health, Human Resources, as well as unemployment. Although IIFW program is focused on empowering the poor to be entrepreneurial, every activity is always associated with population problems. Thus the concept is like the proverb saying that: "Two islands are exceeded in once rowing." If IIFW succeed, other problems, including poverty, will be overcome and opening a business will have a high multiplier effect.

Revitalizing IIWF policy is a multi-sector policy. This is a government policy to synergize several sectors and open some opportunities for all parties to participate in developing IIWF through productive economic activities. It is expected that such a policy will have a positive impact on many sectors. The family's economic independence is very important considering that poverty will not only affect the economic problems but also will impact on other issues such as life attitudes, family education, health and others the quality of human resources in Indonesia. Strong IIWF requires synergicity of all parties to find some solutions to existing problems. Through mutualistic symbiosis paradigm the business continuity will be more assured. They are be able to help each other to promote the products and encourage others to keep trying.

\section{Suggestion}

The target of IIWF program in the future can be more flexible and progressive. It is not only for the poor but also for the middle class who are interested in joining IIWF. It is not only for the married people but also for the youth or youth groups who have already joined as the volunteers in many activities related to Family Planning. Thus, it is expected that IIWF will become the subject of the progress in joining the family welfare. It is no longer the object of the program.

A strategy to increase the number of Family Planning acceptors by IIWF is a multisector policy. It is the Indonesian government's policy to synergize several sectors and open some opportunities to run a business to develop IIWF through the productive economic activities. It is expected that such a policy will have the positive impact on many sectors. The family's economic independence is very important considering that poverty will not only affect the economic problems but also will affect other issues such as life attitudes, family education, health and so on. It will also affect the participation of family planning programs.

\section{References}

Anoname. (2011: 1). Pusat Penelitian dan Pengembangan KB-KS - Badan Kependudukan dan Keluarga, Berencana Nasional. 
Dewi, A. (n.d.). Rancangan Model Implementasi Program Keluarga Berencana Di Era Demokrasi Melalui Peningkatan Partisipasi Masyarakat Di Jawa Timur, Hibah Bersaing- DIKTI.

Harian Bernas Jogja, S. (2013, July 22). Kembangkan UMKM Berbasis Kelompok UPPKS.

http://kaltim.bkkbn.go.id/lists/artikel/dispform.aspx?id=136\&contenttypeid=0x01003dcababc04b7084595da364 423de7897, dikutip 7 agustus 2012

http://kebumen.ipkbjateng.web.id/2014/03/blog-post_14.html

Irianto, H. (2001). Metode Penelitian Kulaitatif. PT RajaGrafindo Persada, Jakarta.

Irianto, H. (2014). Rancangan Model Sinergisitas Implemnetasi Kebijakan Corporate Social Responsibility (CSR) Dalam Penanggulangan Pengangguran Terdidik Melalui Program Kewirauasahaan, Penelitian Hibah Bersaing DIKTI.

LismomonNata. $\quad$ (2012, $\quad$ August $\quad 9)$ from http://sumbar.bkkbn.go.id/Lists/Artikel/DispForm.aspx?ID=37\&ContentTypeId=0x01003DCABABC04B7 084595DA364423DE7897

Nurwati Nunung. (2006). Survey Dampak Program KB dan Manajemen Pengelolaan Program KB di kota Bandung. Pusat Penelitian Kependudukan dan Pengembangan Sumber Daya Manusia Universitas Pdjadjaran.

Sarwirini. (n.d.). Rancangan Model Pemberdayaan Keluarga Untuk Mencegah Terjadinya Tindak Kekerasan Dalam Rumah Tangga (Kdrt) Di Jawa Timur.

Sudarsono. (2009). Family Resilience Sebagai Penyelamat Keluarga. Majalah Ilmiah Maranatha, 16(1). Universitas UK Maranatha, Bandung.

Susanti, I. (2013). Manfaat Hasil Penyuluhan (UPPKS) Dalam Upaya Pemberdayaan Ekonomi Keluarga. S1 Universitas Pendidikan Indonesia. Retrieved from http://repository.upi.edu/4305/

UU No 10 Tahun. (1992). Tentang Perkembangan Kependudukan Dan Pembangunan Keluarga Sejahtera.

UU No. 10 th. (1992a). Inpres No.3 Th. 1996, Perpres No. 7 Th 2005, dan Komitmen Global tentang MDGs Mellinium Develoment Gold.

UU No. 10 th. (1992b). Inpres No.3 Th. 1996, Perpres No. 7 Th 2005, dan Komit.

YulaechaPadma. http://bkbpppa.tanahbumbukab.go.id/index.php?option=com_content\&view $=$ article $\& \mathrm{id}=140$ : sosialisasi-uppks\&catid=35:berita-terkini\&Itemid $=28$

\section{Copyrights}

Copyright for this article is retained by the author(s), with first publication rights granted to the journal.

This is an open-access article distributed under the terms and conditions of the Creative Commons Attribution license (http://creativecommons.org/licenses/by/4.0/). 